\title{
The limitations of IgM assays in the serological diagnosis of Mycoplasma pneumoniae infections
}

\author{
MARGARET SILLIS
}

\begin{abstract}
Virology Department, PHLS/Microbiology Laboratory, West Norwich Hospital, Bowthorpe Road, Norwich NR2 3TX
\end{abstract}

\begin{abstract}
Summary. The most useful and reliable serological investigations for the diagnosis of current Mycoplasma pneumoniae infection, including reinfection, were investigated. Paired sera and respiratory specimens from 115 patients with lower respiratory tract symptoms were examined for evidence of current $M$. pneumoniae infection by serological response, as measured by complement-fixation and indirect immunofluorescence tests for specific $\operatorname{IgM}, \operatorname{IgA}$ and $\mathrm{IgG}$, and also by culture of $M$. pneumoniae from respiratory material. Specific IgM was not always detectable in cases where other criteria indicated current or recent infection. On the basis of the present results, it is postulated that primary infection and reinfection may be differentiated by the presence or absence of specific IgM in the presence of elevated specific IgA levels and, therefore, that estimation of both $\operatorname{IgM}$ and $\operatorname{IgA}$ is necessary for the maximal detection of current $M$. pneumoniae infection, including reinfections. Specific IgG levels remained elevated for many weeks and were not useful diagnostically.
\end{abstract}

\section{Introduction}

Mycoplasma pneumoniae is recognised as the only mycoplasma species that is unequivocally a primary pathogen in man, causing disease manifestations ranging from asymptomatic respiratory infection to severe pneumonia. ${ }^{1}$ The organism is sensitive to erythromycin and tetracyclines, but not to the drugs usually given routinely as initial therapy in acute pneumonia. Therefore, rapid, reliable laboratory diagnosis is important for this infection.

Because of its fastidious nature, culture of $M$. pneumoniae is difficult and far too slow to be of clinical use; hence, serology remains the prime diagnostic tool. The commonly used complement fixation $(C F)$ test is of limited value, ${ }^{2,3}$ having technical problems or producing inconclusive results in many cases, due mainly to difficulties in interpreting moderately elevated titres of specific antibody that could derive from an earlier infection. The specificity of the lipid antigen involved in this test has also been challenged. ${ }^{2}$ Detection of specific IgM antibody, which characteristically appears early in most microbial infections ${ }^{4}$ and has a short half-life, is ideally suited for rapid diagnosis of recent or current infection. The indirect immunofluorescence and IgM-capture enzyme immunosor-

Received 12 Feb. 1990; revised version accepted 15 May 1990. bent assays (EIA) described by Wreghitt and Sillis ${ }^{5}$ have proved very useful for detecting $M$. pneumoniae IgM. However, reinfection with $M$. pneumoniae is reported to be common ${ }^{6,7}$ and it is widely believed that the IgM response is either minimal or undetectable in reinfections with some microbial agents. ${ }^{8}$ If the latter is true also for $M$. pneumoniae, reliance on specific IgM alone as a diagnostic tool could allow some infections to be missed.

In the study reported here, the serological response in patients with and without presumed $M$. pneumoniae infections was examined, supplemented where possible by culture for the organism, to elucidate the limits of reliability of the rapid IgM methods and to determine the most useful testing protocol for serological detection of current or recent infection.

\section{Materials and methods}

The cases represented in this investigation comprised 115 patients with suspected $M$. pneumoniae infection studied during the 1978-1979 epidemic period. Every patient presenting with acute or persisting chest infection, and from whom both paired sera (acute and convalescent) and acute respiratory material (sputum or throat swab) were available for serological testing or cultivation, respectively, was included in the study.

Sera were separated at $37^{\circ} \mathrm{C}$ and tested for the presence of cold agglutinins (CA), $M$. pneumoniae complement- 
fixing antibody and $M$. pneumoniae-specific $\operatorname{IgM}, \operatorname{IgA}$ and $\mathrm{IgG}$ as detected by indirect immunofluorescence (see below).

\section{Cold agglutination test}

Sera were used at dilutions of 10, 20 and 40 in phosphate-buffered saline (PBS), pH 7.0, in $0.5-\mathrm{ml}$ volumes in tubes, to each of which was then added $0.5 \mathrm{ml}$ of a washed $0.5 \%$ suspension of human Group-O redblood cells in PBS. The tubes were placed at $4^{\circ} \mathrm{C}$ overnight or for a minimum of $2 \mathrm{~h}$. For reading the result, the tubes were tapped once to dislodge any sedimented red cells; any agglutination pattern observed with the naked eye was recorded as positive and a buttoned deposit that dispersed as a fine suspension as negative. Tubes were placed at $37^{\circ} \mathrm{C}$ for $30 \mathrm{~min}$ to check that elution of the agglutinin had occurred, resulting in disappearance of the agglutination pattern. A titre of $>20$, although non-specific, was taken as suggestive of recent or current $M$. pneumoniae infection.

\section{Complement-fixation test}

The method of Bradstreet and Taylor ${ }^{9}$ was employed in a conventional overnight-fixation test with 3HD50 of Richardson's preserved complement (Tissue Culture Services Ltd) and haemolytic serum (Sera Lab Ltd). The $M$. pneumoniae antigen was supplied by the Division of Microbiological Reagents and Quality Control (DMRQC), Central Public Health Laboratory, $61 \mathrm{Col}-$ indale Avenue, London NW9 5HT. Sera were tested in twofold dilutions, initially at 4-128, and were read at the $50 \%$ end-point level. Further dilutions to 1024 were tested if necessary. Presence of a CF antibody titre $>128$ or a fourfold rise or fall over more than 7 days was regarded as diagnostically positive.

\section{Indirect immunofluorescence test (IFA)}

The slide test with $M$. pneumoniae suspensions as antigen, as described by Wreghitt and Sillis, ${ }^{5}$ was used to assess $M$. pneumoniae-specific IgM, IgA and IgG in patients' sera tested in twofold dilutions at 4-128. Presence of a specific IgM titre of $>4$, or a specific IgA titre $>8$, or a fourfold rise or fall in the latter, was taken to indicate recent or current $M$. pneumoniae infection.

\section{Culture procedure}

Samples of sputum, mucolysed with $\mathrm{N}$-acetyl cysteine $2 \%$, ${ }^{10}$ or throat swab washings in virus transport medium $(2 \mathrm{ml})$, were inoculated in $0 \cdot 2-\mathrm{ml}$ volumes on to agar and into $2 \mathrm{ml}$ of broth medium, as described below. A further 100 -fold dilution in broth was also made. Plates were incubated at $37^{\circ} \mathrm{C}$ in $\mathrm{CO}_{2} 5 \%, \mathrm{~N}_{2} 95 \%$ and examined microscopically for colonies at 3-4-day intervals for up to 3 weeks. Positive cultures were confirmed by growth inhibition tests with specific mycoplasmal antiserum disks issued by DMRQC. Broth cultures were incubated at $37^{\circ} \mathrm{C}$ and examined at intervals for colour change and were discarded after 3 weeks if no colour change had occurred. Broth cultures showing a colour change indicating acidification, but without evident turbidity, were subcultured on to agar medium and any resulting colonies identified as above. Broths that became turbid before day 7 were assumed to be bacterially contaminated and were discarded; any becoming turbid after day 7 were filtered through a $450-\mathrm{nm}$ average-pore-diameter membrane filter and $0.5 \mathrm{ml}$ of the filtrate was inoculated into $2 \mathrm{ml}$ of fresh broth medium, which was incubated and further examined as above.

\section{Media}

The agar medium comprised PPLO agar base (Oxoid) $70 \% \mathrm{v} / \mathrm{v}$, porcine serum (Tissue Culture Services Ltd; heated at $56^{\circ} \mathrm{C}$ for $30 \mathrm{~min}$ ) $10 \% \mathrm{v} / \mathrm{v}$, yeast extract (Oxoid L21) $10 \%$ of $7 \% \mathrm{v} / \mathrm{v}$, thallous acetate (Sigma) $0.25 \mathrm{~g} / \mathrm{L}$, benzylpenicillin 200 units $/ \mathrm{ml}$, boiled-blood extract, prepared by a modification of a method described by Klieneberger-Nobel ${ }^{11}$ from defibrinated horse blood (Tissue Culture Services Ltd), $10 \% \mathrm{v} / \mathrm{v}$ and DNA (calf thymus; BDH Chemicals) $0.02 \mathrm{~g} / \mathrm{L}$. Glucose broth medium consisted of PPLO broth base (Oxoid) $70 \% \mathrm{v} / \mathrm{v}$, horse serum $20 \% \mathrm{v} / \mathrm{v}$, glucose $1 \% \mathrm{v} / \mathrm{v}$ yeast extract $10 \%$ of $7 \% \mathrm{v} / \mathrm{v}$, penicillin and thallous acetate as in the agar medium, and phenol red $1 \mathrm{~g} / \mathrm{L}$ as $\mathrm{pH}$ indicator. The $\mathrm{pH}$ of the broth was adjusted to $\mathrm{pH} 7.8$ with $1 \mathrm{~N} \mathrm{NaOH}$ solution.

\section{Other investigations}

Mucolysed sputum samples were routinely cultured on bacteriological media for respiratory bacterial pathogens and sera were tested by the CF test to detect antibodies to adenovirus, Influenza A, Influenza B, Chlamydia spp. and Coxiella burnetii.

\section{Results}

More than half $(63 \%)$ of the 115 cases examined showed evidence of recent $M$. pneumoniae infection by serological criteria and nearly half $(45 \%)$ by isolation of the mycoplasma (table I). The table also indicates how these results can be categorised in four groups, on the basis of the IgM results in relation to the other serological and isolation criteria. Group 1 comprised all the cases that showed positive results in tests for IgM. The other three groups comprised cases with negative results for IgM, with different categories of presumedpositive criteria by the other tests. In Group 2, all test categories contained positive results; in Group 3 , only the CF results were positive (apart from one serum that was positive by $\mathrm{CA}$ ); in Group 4, all criteria (except for $\mathrm{CA}$ in 4 patients) were negative. 
Table I. Summary of serological and culture results for the 115 patients studied

\begin{tabular}{cc|ccccc}
\hline & & \multicolumn{4}{c}{ Number (\%) in each group that gave positive results by the } \\
following criteria:
\end{tabular}

* 43 on presentation.

$\uparrow 21$ on presentation.

$\ddagger$ Absence of IgM confirmed by IgM-capture EIA ${ }^{5}$ and CF and IFA after SDG fractionation.

$\S$ Fourfold rise in 8 .

The 50 patients in Group 1 were those with detectable levels of specific IgM, together with other positive serological markers indicating $M$. pneumoniae infection. Isolation of the organism was successful from 40 of these patients; 40 patients in the group also had a CA titre $>20$. Forty-one patients were admitted into hospital. Significant titres of specific IgM were detected at presentation in $43(86 \%)$ patients and seven developed IgM later; only 21 patients had CF titres $>128$. Peak antibody levels (CF and IF) were demonstrated at presentation in 24 patients; all but two of these were hospital admissions. Of the remaining 26 patients with still-rising titres, seven were not hospital admissions. Eight patients in Group 1 never manifested any of the CF-antibody positive criteria.

In the 14 patients in Group 2, serological evidence of $M$. pneumoniae infection was demonstrated in the absence of detectable specific IgM antibody. From all but two, the mycoplasma was cultivated. A detailed breakdown of results for this group is shown in table II. Positive CA titres $(>20)$ were detected in the sera of only two patients. Three patients were admitted into hospital. Eight patients in this group never produced CF antibody titres at a level regarded as diagnostic $(>128)$ during the period studied. The absence of specific IgM in sera from this group was confirmed by use of an IgMcapture EIA technique ${ }^{5}$ or by sucrose density gradient (SDG) fractionation of sera, ${ }^{12}$ followed by CF and IFA tests.

The 10 patients in Group 3 had positive CF criteria as the only evidence of $M$. pneumoniae infection. Absence of IgM was confirmed by IgMcapture EIA and SDG fractionation. The remaining 41 patients, comprising Group 4, showed no serological or cultural evidence of $M$. pneumoniae infection, except that CA titres $>20$ were detected in four of these cases.

An incidental observation was that the quality of the fluorescence in the IFA IgG assay produced by sera in Groups 1 and 2 was different from that for Groups 3 and 4; the former was extremely bright, compared with a much duller fluorescence in the latter.

\section{Discussion}

Two clearly defined patterns of positive serological response were observed in patients with $M$. pneumoniae infection as diagnosed on the basis of the above criteria, one showing a marked level of specific IgM (Group 1) and the other having minimal or no specific IgM, but elevated or rising or falling titres of specific IgA, IgG or CF antibody (Group 2). Alternative explanations may be offered to account for the negative IgM response in the latter group.

Firstly, these patients may have had an impairment of the IgM limb of the antibody response. However, four patients did produce detectable CAs, which belong to the IgM class. Secondly, as prolonged shedding of $M$. pneumoniae from the respiratory tract is known to occur for up to 7 months after acute illness, ${ }^{13}$ it could be argued that the patients in Group 2 were prolonged excreters following a mycoplasma infection that had occurred 
Table II. Details of results for patients in Group 2

\begin{tabular}{|c|c|c|c|c|c|c|c|c|c|}
\hline \multirow{2}{*}{$\begin{array}{l}\text { Case } \\
\text { no. }\end{array}$} & \multirow{2}{*}{$\begin{array}{c}\text { Age } \\
\text { (years) }\end{array}$} & \multirow[b]{2}{*}{ Sex } & \multirow{2}{*}{$\begin{array}{l}\text { Time after } \\
\text { onset (days*) }\end{array}$} & \multirow{2}{*}{$\begin{array}{c}\text { Culture of } \\
\text { M.pneu- } \\
\text { moniae }\end{array}$} & \multirow[b]{2}{*}{ CF titre } & \multicolumn{3}{|c|}{$\begin{array}{l}\text { M. pneumoniae-specific } \\
\text { immunoglobulin titres }\end{array}$} & \multirow{2}{*}{$\begin{array}{c}\text { Cold agglu- } \\
\text { tinins } \\
\text { (titre) }\end{array}$} \\
\hline & & & & & & IgM & $\operatorname{Ig} A$ & IgG & \\
\hline 1 & 7 & $\mathrm{~F}$ & $\begin{array}{c}0 \\
+15 \ddagger\end{array}$ & $\begin{array}{l}+ \\
-\end{array}$ & $\begin{array}{l}16 \\
32\end{array}$ & $\begin{array}{l}<4 \\
<4\end{array}$ & $\begin{array}{l}4 \\
4\end{array}$ & $\begin{array}{l}4 \\
8\end{array}$ & $\begin{array}{l}<20 \\
<20\end{array}$ \\
\hline $2 \dagger$ & 22 & $\mathbf{M}$ & $\begin{array}{l}10 \\
20\end{array}$ & + & $\begin{array}{r}16 \\
256\end{array}$ & $\begin{array}{l}<4 \\
<4\end{array}$ & $\begin{array}{r}8 \\
32\end{array}$ & $\begin{array}{r}8 \\
64\end{array}$ & $\begin{array}{l}<20 \\
<20\end{array}$ \\
\hline \multirow[t]{2}{*}{3} & 26 & F & 6 weeks & $\stackrel{+}{+} \underset{\text { (onset) }}{ }$ & 128 & $<4$ & 32 & 128 & $<20$ \\
\hline & & & 6 months & & 32 & $<4$ & 16 & 128 & $<20$ \\
\hline 4 & 25 & $\mathbf{M}$ & $\begin{array}{l}14 \\
25\end{array}$ & + & $\begin{array}{r}128 \\
>512\end{array}$ & $\begin{array}{l}<4 \\
<4\end{array}$ & $\begin{array}{l}16 \\
64\end{array}$ & $\begin{array}{l}>128 \\
>128\end{array}$ & $\begin{array}{l}<20 \\
<20\end{array}$ \\
\hline 5 & 20 & $\mathbf{M}$ & $\begin{array}{l}14 \\
35\end{array}$ & + & $\begin{array}{r}8 \\
32\end{array}$ & $\begin{array}{l}<4 \\
<4\end{array}$ & $\begin{array}{r}4 \\
16\end{array}$ & $\begin{array}{r}8 \\
64\end{array}$ & $\begin{array}{l}<20 \\
<20\end{array}$ \\
\hline 6 & 38 & F & $\begin{array}{l}12 \\
34\end{array}$ & - & $\begin{array}{l}256 \\
256\end{array}$ & $\begin{array}{l}<4 \\
<4\end{array}$ & $\begin{array}{l}128 \\
128\end{array}$ & $\begin{array}{l}>128 \\
>128\end{array}$ & $\begin{array}{l}80 \\
20\end{array}$ \\
\hline $7 \dagger$ & 60 & $\mathbf{M}$ & $\begin{array}{l}14 \\
18\end{array}$ & + & $\begin{array}{r}256 \\
>512\end{array}$ & $\begin{array}{l}<4 \\
<4\end{array}$ & $\begin{array}{r}4 \\
16\end{array}$ & $\begin{array}{r}64 \\
>128\end{array}$ & $\begin{array}{l}<20 \\
<20\end{array}$ \\
\hline 8 & 31 & $F$ & $\begin{array}{l}11 \\
54\end{array}$ & + & $\begin{array}{r}16 \\
128\end{array}$ & $\begin{array}{l}<4 \\
<4\end{array}$ & $\begin{array}{r}4 \\
16\end{array}$ & $\begin{array}{r}16 \\
128\end{array}$ & $\begin{array}{l}<20 \\
<20\end{array}$ \\
\hline 9 & 33 & $\mathbf{M}$ & $\begin{array}{l}15 \\
28\end{array}$ & + & $\begin{array}{r}8 \\
64\end{array}$ & $\begin{array}{l}<4 \\
<4\end{array}$ & $\begin{array}{r}4 \\
32\end{array}$ & $\begin{array}{r}4 \\
64\end{array}$ & $\begin{array}{l}<20 \\
<20\end{array}$ \\
\hline 10 & 39 & $\mathbf{M}$ & $\begin{array}{l}14 \\
35\end{array}$ & + & $\begin{array}{r}32 \\
128\end{array}$ & $\begin{array}{l}<4 \\
<4\end{array}$ & $\begin{array}{l}16 \\
64\end{array}$ & $\begin{array}{r}64 \\
256\end{array}$ & $\begin{array}{l}<20 \\
<20\end{array}$ \\
\hline 11 & 51 & $\mathbf{M}$ & $\begin{array}{r}7 \\
14 \\
28\end{array}$ & + & $\begin{array}{r}16 \\
128 \\
128\end{array}$ & $\begin{array}{l}<4 \\
<4 \\
<4\end{array}$ & $\begin{array}{r}4 \\
16 \\
128\end{array}$ & $\begin{array}{r}32 \\
128 \\
>128\end{array}$ & $\begin{array}{r}<20 \\
40 \\
<20\end{array}$ \\
\hline 12 & 46 & $\mathbf{M}$ & $\begin{array}{c}-1 \text { year } \\
4 \\
16\end{array}$ & + & $\begin{array}{r}4 \\
4 \\
>512\end{array}$ & $\begin{array}{l}<4 \\
<4 \\
<4\end{array}$ & $\begin{array}{r}4 \\
4 \\
64\end{array}$ & $\begin{array}{r}8 \\
16 \\
128\end{array}$ & $\begin{array}{l}<20 \\
<20 \\
<20\end{array}$ \\
\hline $13 \dagger$ & 54 & $\mathbf{M}$ & $\begin{array}{r}7 \\
15\end{array}$ & - & $\begin{array}{r}<4 \\
64\end{array}$ & $\begin{array}{l}<4 \\
<4\end{array}$ & $\begin{array}{r}4 \\
32\end{array}$ & $\begin{array}{r}4 \\
128\end{array}$ & $\begin{array}{l}<20 \\
<20\end{array}$ \\
\hline 14 & 34 & F & $\begin{array}{r}3 \\
13\end{array}$ & + & $\begin{array}{l}256 \\
256\end{array}$ & $\begin{array}{l}<4 \\
<4\end{array}$ & $\begin{array}{l}64 \\
64\end{array}$ & $\begin{array}{l}>128 \\
>128\end{array}$ & $\begin{array}{l}<20 \\
<20\end{array}$ \\
\hline
\end{tabular}

* Unless otherwise indicated.

† Admitted into hospital.

‡ Asymptomatic patient; contact in family outbreak.

several months before the present illness, which may have been caused by another agent. Biberfeld ${ }^{14}$ noted that prolonged excretion was not necessarily associated with a prolonged IgM response. However, the Group-2 patients were also examined both serologically and by culture for other microbial pathogens, with negative results. Furthermore, most (10) of the 13 patients in Group 2 had evidence of recent infection, as manifested by a significant rise in titre of $M$. pneumoniae $\mathrm{CF}, \operatorname{IgA}$ and $\mathrm{IgG}$ antibody during the course of the current illness. However, in the other three patients with high unchanging levels of $\mathrm{CF}, \mathrm{IgA}$ and $\mathrm{IgG}$ antibody (cases $1,6,14$ ), the possibility that these infections occurred some months previously remains a possible explanation of the absence of detectable IgM.

With regard to the anomalous case (patient 1 ) in Group 2, where $M$. pneumoniae was isolated once but not 15 days later, transient carriage of $M$. pneumoniae in the upper respiratory tract must be considered. The child was a contact in a confirmed family outbreak, but never became ill during the period in which the family was studied. It is conceivable that this patient (table II) experienced a re-exposure to the organism at a time when her local immunity had been boosted sufficiently to prevent multiplication of the organism, thus preventing both clinical disease and detectable boost- 
ing of serum antibody apart from a minimal IgG response. This explanation is consistent with the hypothesis of Fernald et al. ${ }^{15}$ who speculated that, because $M$. pneumoniae attaches only superficially and never penetrates the lung parenchyma, ${ }^{16}$ several exposures to the organism may be necessary to produce pulmonary disease, particularly in the absence of the host's local immune response. Consequently, if the host's exposure-intervals to $M$. pneumoniae were frequent, local immunity would be boosted sufficiently to contain its multiplication and thereby prevent development of the disease.

It is tempting to speculate that all the cases in Group 2 represent reinfections with $M$. pneumoniae, whereas those in Group 1 represent primary infections. Many workers have observed agedependent differences in antibody response in patients under 20 years of age, compared with those over 40 years, ${ }^{12,14}$ and a decrease in IgM : IgG ratio with age, suggestive of re-infections in the older age group. ${ }^{17}$ Although there was no appreciable difference in the average age of patients in Groups 1 and 2, there is evidence of an age bias in this study which could have limited the number of young patients included, due to the reluctance of clinicians to venepuncture children unless absolutely necessary. As children comprise the agegroup most likely to have primary infections, any bias against their inclusion would be more likely to reflect upon Group 1. Only $12 \%$ of patients in this study were less than 10 years of age, whereas this age-group accounted for $30 \%$ of routine $M$. pneumoniae diagnostic investigations during this period.

Umetsu et al. ${ }^{20}$ found a rise of CF and IgG titres in four patients with pre-existing $M$. pneumoniae antibody after presumed $M$. pneumoniae reinfection, but no detectable specific IgM in two cases, although there was a good IgM response in one patient who had two well-separated episodes of apparent $\boldsymbol{M}$. pneumoniae infection. The pattern of response in the two IgM-negative patients corresponds with that noted for most of our Group-2 patients.

The observed differences in serological response could possibly be linked to the severity of the disease caused by $M$. pneumoniae, although this might merely reflect the different response between primary (usually invasive) and secondary infections. Cordero et al. ${ }^{18}$ noted a trend towards higher antibody titres after clinical illness, compared with those after asymptomatic infections, but a study by Taylor-Robinson et al. ${ }^{19}$ did not confirm these findings. In the present study, $82 \%$ of Group-1 patients were admitted into hospital compared with $22 \%$ in Group 2 ; this criterion is probably a reliable indicator of the relative severity of illness in the two groups. Thus, reinfection with $M$. pneumoniae and associated factors of age and severity of disease clearly would offer the most credible explanation of the differences in serological response in Groups 1 and 2 , with the exception of patient 1 .

The 10 patients in Group 3, who had positive CF criteria as the only evidence suggesting $M$. pneumoniae infection, could not be compared usefully with those of other groups. In view of the questionable specificity of the lipid antigen used in this test ${ }^{2}$ and the known long-term persistence of IgG from previous infections, this evidence alone was regarded as insufficient for reliable diagnosis of mycoplasma infection. The remaining 41 patients in Group 4 had negative specific serological and cultural criteria, indicating that their illnesses were not a result of $\boldsymbol{M}$. pneumoniae infection.

The temporal distribution of the different antibody classes varies ${ }^{11}$ and, although the peaks of $M$. pneumoniae-specific IgM, IgA, IgG and CF antibody are almost synchronous, occurring at 2-3 weeks after onset of illness, they show markedly different rates of decay. ${ }^{11}$ IgM declines to insignificant levels 3 months after onset in most cases and IgA over 4-5 months, but specific IgG and CF antibodies remain elevated for many months. ${ }^{11}$ Thus it should be stressed that only specific IgM and elevated (titre $>8$ ) IgA levels are diagnostically reliable for detecting recent $M$. pneumoniae infection.

The proportions of the four subclasses of $\mathrm{IgG}$ are known to alter during the course of an infection. ${ }^{21}$ The predominance of one particular subclass at any one time, or differences in antibody avidity, may explain the aforementioned qualitative difference in the fluorescence observed in the IFA IgG assay in patients from Groups 1 and 2, compared with those in Groups 3 and 4.

In the present study, the concurrent investigations of $M$. pneumoniae-specific IgM, IgA and IgG titres detected $99 \%$ of all $M$. pneumoniae infections, whether primary infections or reinfections, as classified according to our criteria, whereas only $78 \%$ of cases - presumed to be primary infectionswere detected by the IgM assay alone. With the paired sera that were available, the CF test detected $86 \%$ of all $M$. pneumoniae infections, but also gave $13 \%$ apparently false-positive results (Group 3), since they were not confirmed by other serological or cultural criteria.

It is concluded from this study that concurrent investigations of $\boldsymbol{M}$. pneumoniae-specific levels of both IgM and $\operatorname{IgA}$ are necessary for the comprehensive, accurate and rapid diagnosis of all $M$. 
pneumoniae infections. In $86 \%$ of the present cases, such a diagnosis could be made by examination of a single serum.

\section{REFERENCES}

1. Ali NJ, Sillis M, Andrews BE, Jenkins PF, Harrison BDW. The clinical spectrum and diagnosis of Mycoplasma pneumoniae infections. $Q J$ Med 1986; 58: 227, 241251.

2. Pönkä A, Pönkä T, Sarna S, Penttinen K. Questionable specificity of lipid antigen in the Mycoplasma pneumoniae complement-fixation test in patients with extrapulmonary manifestations. J Infect 1981, 3: 332-338.

3. Kleemola $\mathbf{M}, \mathbf{K}$ ayhty $\mathbf{H}$. Increase in titres of antibodies to Mycoplasma pneumoniae in patients with purulent meningitis. J Infect Dis 1982; 146: 284-288.

4. Svehag SE. Antibodies to biologically active molecules. Proc Fed Eur Biochem Soc, Vienna 1965; 1: 301-349.

5. Wreghitt TG, Sillis M. A $\mu$-capture ELISA technique for detecting Mycoplasma pneumoniae IgM: comparison with indirect immunofluorescence and indirect ELISA. J Hyg (Camb) 1985; 94: 217-227.

6. Foy HM, Kenny GE, Sefi R, Ochs HD, Allan ID. Second attacks of pneumonia due to Mycoplasma pneumoniae. $J$ Infect Dis 1977 ; 135 : 673-677.

7. Foy HM, Kenny GE, Cooney MK, Allan ID, van Belle G. Natural acquired immunity to pneumonia due to Mycoplasma pneumoniae. J Infect Dis 1983; 147: 967973.

8. Cradock-Watson JE, Ridehalgh MKS, Anderson MJ, Pattison JR. Outcome of asymptomatic infection with rubella virus during pregnancy. $J$ Hyg (Camb) 1981; 87: $147-154$.

9. Bradstreet CMP, Taylor CED. Technique of complementfixation test applicable to the diagnosis of virus diseases. Monthly Bull Min Health PHLS 1962; 21 : 96-104.

10. Woodhams A, Mead G. A comparison between pancreatin and $\mathrm{N}$-acetyl-L-cysteine as sputum liquefying agents for the culture of organisms. Tubercle $1965 ; 46: 224-226$.

11. Klieneberger-Nobel E. Pleuropneumonia-like organisms (PPLO), Mycoplasmataceae. London: Academic Press, $1962 ;$ IV, 58.
I am grateful to Miss Claire Stuart for typing the manuscript and Dr R. H. Leach for constructive comments.

12. Chamberlain P, Saeed AA. A study of the specific IgM antibody response in Mycoplasma pneumoniae infection in man. J Hyg (Camb) 1983; 90: 207-211.

13. Foy HM, Grayston JT, Kenny GE, Alexander ER, McMahan R, Epidemiology of Mycoplasma pneumoniae infection in families. JAMA 1966; 197 : 859-866.

14. Biberfeld G. Antibody responses in Mycoplasma pneumoniae infection in relation to serum immunoglobulins, especially IgM. Acta Pathol Microbiol Scand B 1971; 79: 620-634.

15. Fernald G, Collier A, Clyde WA. Respiratory infections due to Mycoplasma pneumoniae in infants and children. Pediatrics 1975; 55: 327-335.

16. Collier AM, Clyde WA, Denny FW. Biologic effects of Mycoplasma pneumoniae and other mycoplasmas from man on hamster tracheal organ culture. Proc Soc Exp Biol Med 1969; 132: 1153-1158.

17. Skaug K, Eng J, Örstavik I, Haug KW. The diagnostic value of determination of IgM antibodies against Mycoplasma pneumoniae by indirect immunofluorescent antibody test. Acta Pathol Microbiol Scand B 1976;84: 170-176.

18. Cordero L, Cuadrado R, Hall CB, Horstmann DM. Primary atypical pneumonia: an epidemic caused by $\mathrm{Myco}$ plasma pneumoniae. J Ped 1967; 71 : 1-12.

19. Taylor-Robinson D, Soběslavský OJ, Jensen KE, Senterfit LB, Chanock RM. Serologic response to Mycoplasma pneumoniae infection. I. Evaluation of immunofluorescence, complement fixation, indirect hemagglutination, and tetrazolium reduction inhibition tests for the diagnosis of infection. Am J Epidemiol 1966; 83: 287298.

20. Umetsu M, Ogawa $S$, Chiba $S$, Nakao $T$. Immune responses in Mycoplasma pneumoniae infections. Tohoku J Exp Med 1975; 116: 213-218.

21. Grauballe PC, Hornsleth A, Hjelt K, Krasilnikoff PA. Detection by ELISA of immunoglobulin G subclassspecific antibody response in rotavirus infections in children. J Med Virol 1986; 18: 277-281. 